\title{
Conversations on Pedagogies of Place and Environment between Brazil and Canada: Contrasting Contexts to Enshroud Content with Empathy ${ }^{1}$
}

\author{
Conversas sobre pedagogias de lugar e meio ambiente entre o \\ Brasil e o Canadá: contrastando contextos com conteúdo encoberto \\ por empatia.
}

\author{
Marcelo Gules Borges ${ }^{2}$ \\ Janet $\mathrm{McVittie}^{3}$
}

Submetido em 15 de setembro e aprovado em 3 de dezembro de 2019.

\begin{abstract}
Based on pedagogical practices in environmental and science education that privilege the concept of place in all dimensions, we explore in this paper the work and experiences of two teacher educators, one in Brazil and one in Canada, as they visit and learn from one another's places. We wonder about unique places and how such different contexts, with different cultures, histories, and geographies, support researchers and their teacher candidates, guiding them to becoming better teachers within a context for addressing current pressing issues: social and ecological justice. While contrasting our different paths, we reflect and discuss our practices with/on empathy and place education. We discussed the power of bringing teacher education to places (and vice-versa). By contrasting places and their unique ontologies and epistemologies with empathy, we developed deeper understanding of the integral role of place in learning, and better ideas for preparing teachers to teach about their contexts.
\end{abstract}

Keywords: Place. Teacher Education. Empathy. Brazil. Canada.

Resumo: Com base em práticas pedagógicas em educação ambiental e em educação em ciências que privilegiam o conceito de lugar em todas as suas dimensões, exploramos neste artigo o trabalho e as experiências de dois professores formadores, um no Brasil e outro no Canadá, a partir de seus encontros e aprendizagens em seus lugares. Nos perguntamos sobre como diferentes lugares e contextos, com diferentes culturas, histórias e geografias, apoiam pesquisadores e seus estudantes de licenciatura para que se tornem melhores educadores dentro de um cenário atual de questões urgentes: justiça social e ecológica. Ao contrastar nossos diferentes caminhos, refletimos e discutimos nossas práticas com/sobre empatia e a educação baseada no lugar. Discutimos o poder de levar a formação de professores aos lugares (e vice-versa). Ao contrastar lugares e suas ontologias e epistemologias únicas com empatia, desenvolvemos uma compreensão mais profunda do papel integral do lugar na aprendizagem e buscamos melhores ideias para preparar futuros educadores no ensino a parir seus contextos. 
Palavras-chave: Lugar. Formação de Professores. Empatia. Brasil. Canadá.

\section{Vignette I: Brazilian Professor in Canada [2012]}

Last day of our trip! I am seated on a rock in the southern Saskatchewan River, close to the water, composing my journal. We are on the third day of our expedition that started in Saskatoon City coordinated by Author 2 (Janet). Thinking about our place-based course that began last spring, I have been really impressed with the time that we spent carefully organizing it in advance. During our classes at the College of Education (University of Saskatchewan), we studied the goals for the trip and looked up the concepts, themes, and sites on a map of the region. We organized all the steps collaboratively. We set up a schedule and decided on our special menu (local, healthy, and organic food as much as possible). We set up our carpool and talked about safety and skills for our long canoeing and camping journey. For a Brazilian researcher interested in environmental education, I wondered what would we meet there? How could everything make sense in order to establish a connection with my trajectory, my research, and our future as teachers? After some hours driving through the prairies, we reached the exact point where we would start our expedition. We were just a small crew composed of undergraduate students, graduate students, and professors (most of them originally from Saskatchewan). With lots of gear, barrels holding our food (to avoid bear attack!) and our canoes, everything was executed with patience. We organized everything with attention, checked our equipment, and formed pairs. The river was our track to each site. At each stop, after explorations and discussions, we built a new meaning for those places marked on the map we had studied. Each location was unique, but connected to each other by their landscapes, making us realize that altogether each point joined with the others to compose our mesh of places. Everyone in the group had the responsibility to care for every other member and, at the same time, the responsibility to make decisions collectively. In each place, we developed pedagogical strategies that connected text and narratives with material and bodily practices in the environment. Everything we did was to be recorded (through writing, sketching, drawing, artifacts from the locales) in our journals. It was meant not only to explain each place we visited, but also to create real situations (material-body-concepts) during the talks. We were totally involved with the different environments, mixing leisure and study. We performed a set of activities in and out of the water. Collectively, we discussed the themes and shared teaching techniques. We analyzed how the materiality of each place described the environmental and social contradictions we found there. We spent time to get to know the locales, to choose the best point for our camping, and to organize the kitchen and canoes. We cooked. For each meal, we repeated the same ritual: the origins and methods of preparing the food. How do the foods connect us with the river and land? We heard what different ways of knowing (science, Indigenous knowledge, religion, and so on) could tell us about the land. We listened to stories from those places. We heard personal stories. We navigated to the past, present, and future. We met Indigenous people and listened to them. We got to know the history and stories of animals, plants, and other beings, and how the First Nations, Métis, 
and settler cultures shaped their lives in the prairies. We shared our trajectories. How amazing it was to see the possibility to talk about the place from many perspectives. We carefully investigated each local site. I felt cold, hungry, and tired. All perceptions that I have kept in my memory I use to signify my trajectory and that of my family as settlers who immigrated from a rural context in southern Brazil to Porto Alegre city (the capital of Rio Grande do Sul) in the 1980s. I have been thinking about to what extent places I passed by have shaped the professor who I am becoming. How all this experience makes me a better professor and more aware of my position and responsibilities in Brazilian education? As a Latin American scholar, I was impressed with the way we inquired about the places (land and water). There is a profound intention in this kind of education to not deny any of the texture, material, bodies, or voices. Through this radical pedagogy in places, we create empathy for each other, respecting our cultural background and thoughts. The experience of immersion in the prairie is more profound than my capacity to put it into words. We simply lived and lived simply the places we passed through.

\section{Vignette II: Canadian professor in Brazil [2015]}

Author 1 (Marcelo) spent time with me in Saskatchewan in 2012. When he went back to Brazil, he completed his dissertation and took a professorial position in a rural education program, located out of the Universidade Federal de Santa Catarina. Three years later, I spent two months in Brazil during my sabbatical, one month on holiday touring through some of the southern states, and one month with Author 1, going along with him as he taught for the rural education program in Florianopolis and in outlying towns. One trip stood out to me, as being most profoundly connected to the questions we ask in our place-based education course in Saskatoon: what happened here, who lived here? What is happening here, who is living here? The trip was on the island of Sta. Catarina, close to the university, but in an amazingly quiet and remote place despite that the island is well occupied by numerous wealthy people from Brazil and other countries. Author 1 invited his class to attend this optional trip, led by one of their peers, but only one student joined us. Thus, there were four of us - our tour guide who was a student in the rural education program, one other student, and Author 1 and myself. The tour guide was Mestizo, having (as for many Brazilians, but more aware of his background) Indigenous and European ancestry. I had been surprised by the lack of recognition of Indigenous people in Brazil. Although many Brazilians could trace to some Indigenous ancestry, Indigenous people are generally ignored, as if they are not seen or that they don't exist. Occasionally, a federal government will acknowledge and attempt to revivify Indigenous culture, but when Indigenous people set up their wares for sale in markets, people walk by them, and purchase goods imported from India instead. This guide noted his mixed background as being Guarani and Portuguese. The tour he led was in traditional Guarani territory, and he talked about cultural traditions, and the evolution of these to fit with the Portuguese settlers. Our tour began near a school in a very small village. Our guide explained that this village had been built by farmers, and these had grown fruits and vegetables. Thus, these people had produced their own food, built their homes out of local materials, and integrated with the Guarani people. As we walked along the trail, he explained that we were going to the fishing village over the hill. The people in the 
fishing village had traded goods with the farm village, and were friends. Often a person would have run from one village to another, leaving a letter in a friend's mail box. A selforganizing mail system. As we walked along the trail, our guide pointed out a species of tree with a large thick trunk. He explained the Guarani tradition: a father planted one of these trees on the birth of a son; when the tree was large enough, the son would be guided to cut it down, and taught to carve a canoe from it; on the completion of his own canoe, the son became a man in his own right. The trail gradually led upwards, and then, at the crest, we looked down onto the tidal lake (Lagoa da Conceição) (open at high tide to the ocean), and the fishing village (Costa da Lagoa Village). A few small fishing canoes were out on the water. We walked along the road that led through the village-a path for people, not for vehicles, since no road connected this village to other villages. Each side of the road, the lake side and hill side, had a house, and the houses were painted bright colours. Each lake-side house had a pier with a brightly painted canoe tied to it. The canoes were the same colours as the houses they belonged to. On nearly every pier, there were a few tables, and a menu - some kind of fish for sale, prepared into a meal. We were nearly the only visitors to the village that day, and certainly the only ones who came by land. We stopped at one pier restaurant, chosen by our guide, and ordered our lunch - a delicious and wholesome meal of fresh fish and local vegetables. Nearby, a young man was refurbishing an old canoe, peeling the rot off it, augmenting the wood, and putting paint on it. He worked meticulously. I envied him the time he had for his labour. We should all have this time for working with our hands, reflecting, conversing with friends, neighbours, family. To move on from the village, we took the water bus. The bus took us past a few more similar villages, which, as we drew closer to the city at the end of the lake, had larger houses and more vehicles. When we arrived at the end of the ride, I realized we were in a city of several thousands of people. How was it that this lake was not used recreationally, the way it would be in Canada, with wealthy people motoring around, screaming and laughing as they pulled skiers behind? Or with amateur fishers, hooks in the water? I envied the lack of exploitation of this area, where the village people could still live quiet and contemplative lives.

\section{Introduction: Place}

We draw on Somerville (2010) for three principles to illuminate our concept of place: relationship to place is constituted in stories and other representations (expressive arts, processes and questions addressed in science, the storying of history, etc.); place learning is local and embodied; and deep place learning occurs through contrasting differences (political contests over territory, ontology, and epistemology). These principles supported our development of emergent placeresponsive pedagogies. However, we add that, while contrasting differences, one should do so with empathy. 
Place is a concept that has been used and is traditionally addressed in many areas of human sciences, including, for instance, geography (MASSEY, 1994; TUAN, 2001), anthropology (LOW; LAWRENCE-ZUNIGA, 2003), social sciences (TUCK; MCKENZIE, 2015), and environmental science (LANG, 2002). The concept of place is a way to localize human experiences and lives, and has been used to inform, describe, and problematize history, environment, and cultures. Those who use place for pedagogy recognize the political dimensions of place, along with perceptual, sociological, ideological, and ecological dimensions (GRUENEWALD, 2003a, TUCK; MCKENZIE, 2015). As Escobar (2001) noted, place is still important to cultures, especially for outlining one's sense of the local, of frontiers, and of power. It is never fixed, and it connects to identity; a person's identity is built in relation to that person's place; identities are as complex as their places.

Place is, of course, constituted by sedimented social structures and cultural practices. Sensing and moving are not presocial; the lived body is the result of habitual cultural and social processes. It is thus imperative that we "get back into place" (CASEY, 1993) and reverse the long-standing disempowerment of place in both modern theory and social life. This means recognizing that place, body, and environment integrate with each other; that places gather things, thoughts, and memories in particular configurations; and that place, more an event than a thing, is characterized by openness rather than by a unitary self-identity. From an anthropological perspective, it is important to highlight the emplacement of all cultural practices, which stems from the fact that culture is carried into places by bodies — bodies are encultured and, conversely, enact cultural practices (ESCOBAR, 2001, p. 143).

Place as a construct refers to its power to produce cultural identity or "personal and cultural identity is bound up with place" (ESCOBAR, 2001, p. 143). A study of place can support an examination of identity creation, and reinvention. One of the characteristics of place is its porosity: connections to, movements through, networks among places mean that places mutually constitute one another (MASSEY, 1994; ESCOBAR, 2001; NESPOR, 2008). Thus, although one can study a place, one has to be cognizant that places are porous, and, indeed, mutually dependent. As Nespor noted: 
The fair-trade coffee I drink as I write this comes from Mexico by way of a grocery store on the other side of town. My clothes got here from several continents over long commodity chains. The music playing on my computer was created in a lot of places but gets here over the Internet from a station in New Jersey. The computer itself was assembled in Malaysia and shipped from Texas. The energy running the computer comes from a distant power plant that burns coal from another state and dumps crap in the air that ends up who knows where (NESPOR, 2008, p. 475).

Despite that place has been a traditional geographical category, despite that places are porous, it is used in anthropological and social theory as a way not only to localize lives and cultures, but through and across places, between schools and communities (SENECHAL, 2007; INGOLD, 2011; BEAMES; HIGGINS; NICOL, 2012), and should be taken up in curriculum (CHAMBERS, 1999; SMITH, 2002; SOBEL, 2004; GRUENEWALD, 2003b; PIERSOL, 2010; SMITH; SOBEL, 2010; CALDERON, 2014).

Individually, we humans are inscribed everywhere we go, and these places materialize in us. All our feelings and meanings are the result of personal, social, and environmental experiences at different scales which are produced by interacting with perceptual, social, ideological, political, and ecological dimensions of our places (GRUENEWALD, 2003a). Place can be as small as a person's room, or as large as the planet. Every place is porous, with movement of goods and peoples in and out. Nonetheless, the local physical and geographic place is integral to provide context for human lives. Yet, we are losing the notion of place, especially in formal education (CHAMBERS, 1999). In education, this is mainly due to structures and the schooling process (CHAMBERS, 1999; GRUENEWALD, 2003a, 2003b; SMITH; SOBEL, 2010); this is reinforced societally by the penetration of social media, which both separates us from the local physical and geographic experience, but also isolates us into silos of likeminded groups. Place provides the context for where and how we live our lives, and it, therefore, should provide the context for education. Our lives and learning become meaningful within the context of place. Given that places are porous, and that many people are growing up with little understanding of what happens just outside their doors, in what ways are places unique, and in what ways is this important? This is something the two authors wished to explore. 
In the vignettes above, Author 1 (Marcelo) wrote about his experience in a course on the South Saskatchewan River. What impressed him were those things that were different than his own experience: time spent organizing the trip with the teacher candidates (pre-service teachers); time spent determining the goals for sites along the route, such that teacher candidates could practice their teaching about the history of those places; menu planning, with the difficulty of acquiring local and organic food; preparation of teacher candidates for safety/canoeing/camping; concern about potential attacks by bears; and, while on the river, searching for appropriate camping sites. Author 2 (Janet) noted aspects of the teacher candidate-led tour on Santa Catarina Island: the quiet location on an otherwise very populated and busy island; that there is so little connection amongst the urban population and the Indigenous peoples of that region; how the people in the two interconnected villages created a mail system for passing letters to one another; the bright colours of the houses and their boats and the attempt at commerce through creating restaurants for sale of fish; and the time for quiet and embodied reflection that these people had. The issues that struck each of us were not necessarily what others, in similar situations would have noticed. For Author 1, that it took time and effort for teacher candidates to plan menus of local and organic food was a surprise, because this is common in Brazil. Not so in Canada, especially in the Canadian province known most for food production! The lack of availability of local and organic food in Saskatchewan is, of course, a political issue, with the province just to the east of Saskatchewan consuming about 60\% local in-season food, and Saskatchewan only 10\% (KUORI, 2013).

By using places in pedagogy we accept and recognize place as both political and as a descriptor (MCKENZIE; BIELER, 2016). As a pedagogical category, place carries the potential to embrace the social and ecological aspects on a daily basis, opening up to illuminate the mundane and integral trivialities of life. What we emphasize with this ontological understanding is that place can be, at the same time, an ordinary category quite able to be assimilated, as well as conceptually relevant, and also as amenable for articulating curriculum. In these terms, it is possible to perceive places and learn from direct experience with them for a variety of "spiritual, political, economic, ecological and pedagogical reasons" (GRUENEWALD, 2003b, p. 7), through engaging in social and 
ecological learning. This can be done, for example, "through friendship, art, literature, satire, poetry, films, media, cultural differences, local/global spaces and community" (MCKENZIE, 2008, p. 369). In the field of education, authors have defended the importance of place for supporting students in coming to love their places and for supporting relevancy in learning (SOBEL, 2004) in general, and for environmental education (GRUENEWALD, 2003b) in particular. There are clear understandings and defenses, in many cases, of critical pedagogy(ies) of place (GRUENEWALD, 2003a; 2003b; 2009; SENECHAL, 2007; CALDERON, 2014).

For pedagogies (plural) of place, we understand educational practices where place is a way to interpret and engage context, as well as to interrupt and contrast ways of being in that context. We use the plural form of pedagogies of place to recognize the complexities of different places, the complexities within places, and the need for different pedagogies for developing an understanding of the people there, to nurture and support the people and their places.

Place can be examined through processes of place-based education, but also approached through traditions like environmental education, sustainability education; as well, the emerging concept of land-based education (CALDERON, 2014; PAPERSON, 2014; SEAWRIGHT, 2014; SIMPSON, 2014; TUCK; MCKENZIE; MCCOY, 2014; WILDCAT, et al., 2014) which is powerful for localizing relational and sociomaterial aspects of place from Indigenous and other ontologies. In formal education, the school's places extend beyond the classroom to include where the teacher walks or wants to walk and where the teacher takes the students (including other classrooms, the school grounds and play yard, the neighbourhood, the city, etc.) and includes the students' experiences of their places. Place means the culture, the history, the ecology, the politics that surround the students. All these are pertinent to the places of the school. The classroom is just one place, and must be seen as interacting with what is, what exists, outside the walls. It is in the spaces geographically in and out of their place, of the before, the now, the after, of within and between the students, that will result in critical learning. Through examination of the context, and then, through contrasting ideas of the context, processes for realizing meaningful, relevant content for pedagogy emerge. This process brings the curriculum 
to life and life to the school. Every place contains learning potential. Place(s) is/are in pedagogy, and pedagogies are in place(s).

It is integral for students to engage with the context of their places, contrasting aspects of their places, such that curricular content is made contextually relevant to them. As students come to understand their places in greater depth, they will come to understand the need to learn tools for analysis and communication - i.e. the curriculum content. However, without also developing empathy, students are unlikely to be able to work towards solutions to the problems that exist in their places. They will learn, through their critical examination of their places, of terrible social injustices; they know, from both mainstream and social media, of the Anthropocene, species extinction, and climate change. To work for positive change, as well as context, the students need contrast and content, to develop empathy.

For example, although in both Canada and Brazil, the issues of locally grown organic food are important to place, and although the need to redress the horrors that were visited on Indigenous peoples by settlers are similar, the two authors, on visiting the place of the "other" noticed aspects of where the one country was ahead and the other behind. Although Canada has a long way to go towards reconciliation with Indigenous peoples, Indigenous peoples are recognized. However, in Saskatchewan, very little attention has been given to the ease with which local organic food could be produced, sufficient to feed all the people in the province most of their food, and still have much food for export (KUORI, 2013).

It was through reflecting about place in our trajectory as professors of teacher education and with our students (teacher candidates/pre-service teachers) in the Brazilian and the Canadian university environment/milieu, that we came to see how critical pedagogy's influence on place-based learning has created a path forward to supporting teacher candidates in caring and working for positive changes, if supported by empathy. We conclude by advocating for the importance of recognizing that we are all always between places, and it is by contrasting places that we produce and change our ways of being in the world. 


\section{Critical Pedagogy: Influence on Place-Based Learning}

Freire is broadly considered one of the foundational creators of critical pedagogy. His framework is characterized as an emancipatory ontology rooted in historical realism. For Freire, society was trapped in a struggle between the oppressors and the oppressed. This struggle was transplanted into peoples' consciousness, by which both the oppressors and oppressed are unable to care about one another, and thus are both dehumanized. Praxis, defined as the reflection upon the world and transforming it through action (reflection in action), brought about interdependence between objectivity and subjectivity (FREIRE, 1989, p. 11), and between oppressor and oppressed. Freire's conception of praxis was nested within the larger context of his dialogical pedagogy. A dialogical pedagogy is an alternative to common forms of learning and can be explained in juxtaposition to Freire's criticism of what he termed the banking model of education; in a dialogic pedagogy, teacher-students pose questions, and student-teachers engage in discussions. Both teachers and students are learners and teachers, although teachers take on more of a guiding role than do students.

Contrasting the relationship between teachers and students in a dichotomy, the banking model was revealed to contain contradictions about reality: "man [sic] is merely in the world, not with the world or with others; man [sic] is spectator, not recreator" (FREIRE, 2005, p. 62). The banking model of education conceptualizes the students as passive recipients of knowledge - spectators. A student as spectator is a metaphor intended to reveal that students are expected to believe in teachers as experts. The teacher becomes the mediator of what students learn through a hierarchical power implicit in the teacher-student relationship where no space is provided for critical thought or inquiry. As an alternative, Freire outlined a problem-posing pedagogy. Open dialogue, as a pedagogical practice, confronts the implicit power of teachers within the banking model of education. Problem-posing education promotes people to be teachers as well as learners in dialogical relationships.

Gruenewald (2003a) introduced Freirean critical perspectives to place-based education. He noted that place-based education tended to take up environmental connections in rural areas, whereas critical pedagogy tended to address issues of social 
justice in urban areas. He argued that rural and urban places needed critical pedagogy, and both should examine social and ecological elements. He termed this approach a critical pedagogy of place (GRUENEWALD, 2003b).

A critical pedagogy of place has the same aim, and identifies "places" as the contexts in which these situations are perceived and acted on. In order to promote conscientização and at the same time teach the reading and writing that are so important to it, Freire advocates, "reading the world" (FREIRE 1998; FREIRE; MACEDO, 1987) as his central pedagogical strategy. Reading the world radically redefines conventional notions of printbased literacy and conventional school curriculum. For critical pedagogues, the "texts" students and teachers should "decode" are the images of their own concrete, situated experiences with the world. According to Freire, "reading the world always precedes reading the word, and reading the word implies continually reading the world" (FREIRE; MACEDO 1987, p. 35).

Seawright (2014, p. 561) classified place-based education into three categories: liberal (for example, CURTISS; THEOBALD, 2000), in which place is the driving force for engaging learners in their curricula, for coming to understand their relationships with their community, and with the more-than-human world; critical, in which there is acknowledgement of the socially constructed nature of place, and of the abuses of white settler privilege, and takes up a critical examination of the damages created by injustice (GRUENEWALD, 2003b); and land-based education, in which a different epistemology is the basis, where the land is conceived of as a set of relationships amongst all beings, animate, inanimate, human and more than human. Garcia and Shirley (2012) define critical Indigenous pedagogy as focusing on social injustices so as to transform inequitable and oppressive power relations. The goal is to empower teachers and students to transform their places, their communities, such that corporations and white governments can no longer exploit Indigenous land. The process of decolonization is critical pedagogy - in the sense of liberating the minds and lands of Indigenous peoples (GARCIA; SHIRLEY, 2012, p. 81), but at the same time decolonizing "is not a metonym for social justice" (TUCK; YANG, 2012, p. 21). Tuck and Yang make clear that decolonization is not just about the minds of people being liberated from the thought processes of the colonizers; it is also about the land. Indigenous peoples have sovereign rights to the land. 
Many authors affirm the absence of critical perspectives in pedagogy of place (TLUSTY; RHOADES, 2006; MCINERNEY; SMYTH; DOWN, 2011). It would happen due to a tendency to see place as a neutral category rather than a concept that can reveal social and environmental contradictions in human lives and cultural beliefs. The critical pedagogy of place we have been following embraces the link between the classroom and cultural politics, and further, it explicitly makes the limits and simulations of the classroom problematic. Tuck and McKenzie (2015, p. 18) argued that "we need to move beyond understandings of place as a neutral backdrop, or as a bounded and antiquated concept, or as only physical landscape, to instead theorize and practice place more deeply in social science research." For the authors, a critical place inquiry should consider places in terms of mobility, concept of land, colonization and settler colonization, human and other nonhuman agency, time and space, and politics of places (TUCK; MCKENZIE, 2015).

Through this, and while retaining the critical (FREIRE, 2005; GRUENEWALD, 2003b) and sociomaterial (TUCK; MCKENZIE, 2015; MCKENZIE; BIELER, 2016) pedagogies in our classes, we support our teacher candidates to understand the sociocultural environment; we do this through using places to develop a set of pedagogies. Our conversation in these last years has been about how to work together to improve/ qualify/decentre our practices of teacher education. We usually start from the places we are in, and teach about space, place, land, territory, environment, and contrast these referents within the available multicultural aspects, present, past, and potential futures. Through place, identity, and diversity, a physical description of reality in multiple forms can be developed and understood more deeply. We use place only partially because of how effective it is for engaging students in their learning of curricular outcomes, so they understand the relevancy of numeracy, literacy, natural sciences, arts, etc. For us, curricular content is meaningful only in that it is necessary for students to move toward achieving worthy goals and changing their immediate worlds to become healthier places.

That humanity is currently facing environmental collapse due to the effects of the Anthropocene (RUDIMAN, 2013), bringing about species loss and climate change, adds urgency to our work. Can the world afford to have teachers who do not teach for the environment and/in places? David Orr (1991) noted that all education is environmental 
education, meaning that if teachers do not teach about the environment explicitly, they are teaching that the status quo is acceptable. The status quo is not acceptable. However, it is overwhelming and depressing for children to learn that their world is a mess and solving the problems is a huge undertaking. That is why, to support them and ourselves in going forward, we need empathy.

\section{Empathy: Importance to Teacher Education in Places}

Webber and Miller (2016) argued that teacher preparation programs remain focused on teaching for subject area specialists, which led to their critique of these kinds of programs:

Conforming to traditional, subject-specific course design may inhibit the creation of the conditions for practicing teachers to be critical of existing processes and systems. While this insight is at least as old as Dewey and assumes even larger dimensions as antioppressive and decolonizing pedagogies, how to teach pre-service teachers to practice integrated, interdisciplinary, and integrated methodologies is not taken up in the teacher education literature, or at least not in the straightforward ways we expected (p. 1063).

In many contexts, environmental education has been taken up as a subject area, where students learn science-oriented concepts about ecosystems, and learn, too, of the damage that is done to the planet. Since teachers care about their students, to ensure they don't become depressed, potential technical solutions are often proposed. We, two authors, remember a time when lessons on how humans would "farm the seas" in the future, harvesting plant life from the oceans, to sustain human life, were taught. The damage that has since been done to the oceans, through plastic pollution, overfishing, oil spills, has meant this technology is not likely to be realized. The seas have become moreor-less toxic soups, and much of the biodiversity of sea-life is under threat. We taught about the hope inspired by the "Green Revolution" which increased crop production from 1960 through the 1980's, but ultimately destroyed or destabilized social and ecological systems. This "Revolution” required new agricultural practices, huge inputs of pesticides, herbicides, and fertilizers, as well as requiring farmers to purchase patented seed, and grow monocultures. The inputs became so expensive that small farmers either had to 
borrow money to purchase more land, crowding out hedgerows and wetlands, or sell their land to large corporations. Whole societies have been destroyed, with rural people shifting to urban slums, unable to find meaningful employment, and no longer producing food for themselves (CAVANAGH; MANDER, 2003; SHIVA, 2015). Above all, these agricultural practices have contributed to climate change and the Anthropocene.

Somehow, teachers must teach that technological solutions to human created problems are not a way forward, and yet, to ensure the students don't just give up in despair, to find ways to support the youth with hope for the future. In this sense, the most common action in order to understand the consequences of the Anthropocene era and climate change in places has been to analyse its causes in terms of science and human and geological history (and thereby teaching updated technological versions of the Green Revolution and of farming the seas). We suggest that in education, our actions should go far beyond. As students engage in the context of their places, contrasting their ways of being to those of others or of the past, to consider actions to take, they learn the content. Place is the content. However, for them to be able to move forward, instead of becoming overwhelmed with despair, they must develop empathy to places (and all its inhabitants) through the same artifice: by the history and stories from different ways of knowing (AIKENHEAD; MICHELL, 2011).

According to Gieser (2008) the term empathy means "feeling-into" and comes from the German word Einfühlung. The same meaning is found in the Greek en pathos ("in suffering/passion"). Used in the context of psychology, in the $20^{\text {th }}$ century, the subject-object relationship was explored. In the field of anthropology, empathy has a long tradition, in which people come to understand others by living their lives with care. In general words, the concept is a way to define the engagement between worlds, lives, or ideas (Gieser) in terms of emotions, and identification. In other words, the "other" matter to me (in our case, "other" is other inhabitants of our places, and of other places). These definitions match closely to what Lugones (1987) described as world travelling with loving perception. Worlds for her were any places inhabited by "flesh and blood people". A person could occupy more than one world at the same time, because those worlds overlapped in space, and even though the different worlds might have different 
ontologies; when one took up one's subjectivity in a different world, one had travelled. For example, she described herself as Latina, or as being constructed as Latina (two forms of her self and therefore, two different worlds). When she moved from being Latina to being constructed as Latina, she travelled from one world to another, and this could happen instantaneously. Lugones wanted us to learn to travel to different worlds with loving perception, which meant, basically, having empathy for others and for other worlds, so as to be open to learning from/with them. For her, loving perception and playfulness meant a person was open to self-construction. Being open to self-construction, for the authors of this paper, is empathy.

From a posthumanist view (BRAIDOTTI, 2013; SNAZA; WEAVER, 2015; RILEY, 2019) empathy is not solely a human emotion. Empathy is something that can be felt by all beings, and must be felt towards all other beings. Empathy can be for places, landscapes, air/water/land, and all species. This empathy (reciprocal in terms of other non-human agents) implies that the agent will be open-minded and attentive to each local place which will inform them in terms of global scale. The agents must attend to what happens here and now and attend to who explains the scene/scenario. Local is not opposed to global but is part of a meshwork (INGOLD, 2011) of agents (humans and other nonhumans) in their wayfarings. In this sense, we need to care for the "cultural and ecological lives of places and understanding how one place is connected to other" (GRUENEWALD, 2003a, p. 624).

This ability to create and developing empathy for places, according to Gruenewald (2003a), is necessary for acting locally in education, in order to produce meaning in schools, systems, and communities. Gruenewald affirmed that curricula should be animated by empathy. Beyond that, this is the basis to create curricula: investigations of local places. Thus, the sense of empathy should be used through respecting the features of places and their inhabitants, embedding them into curriculum as the first action to learning objectives. Taking up Abram's (1997) phenomenological analysis of places, Gruenewald developed the idea that students and teachers need 
attentiveness and rejuvenation of carnal empathy with place can be read as a challenge to the way that schools, through their regimes of bodily control (FOUCAULT, 1977), currently blunt our ability to perceive (GRUENEWALD, 2003b, p. 625.

This carnal empathy (bodily oriented) considers the discontinuities of our bodies and our limitations (as humans) to represent our experiences. We cannot perceive humans (or others' places) only as objects "but also as sensuous or feeling body" (GIESER, 2008, p. 309). In terms of education, this is an "empathic learning process that is concerned with both the perception of the environment and the experience of the teacher" (GIESER, 2008, p. 311).

Empathy to places implies engagement with all their inhabitants, beings, communities, their histories and stories. It is the capacity to go beyond humanism but, at the same time, maintaining our solidarity for humans, lives, and contradictions and injustices in places. From our experiences, place in education is not an arena for academic and epistemic disputes but rather a process for transposing and sequencing narratives that would amplify student actions to support the health of their places. Regarding place in education, teacher education in the Anthropocene era requires as a first strategy to foster empathy for the familiar (SOBEL, 1999). We authors, and our teacher candidates, must be open to self-construction through our experiences in places, as we world travel through coming to understand our places in different ways (LUGONES, 1987).

\section{How We Have Brought Teacher Education to Places (and vice-versa)}

The vignettes that open this paper were written in different moments. As snapshots of fully lived and experienced participation for each of us in the other's country, they express the empathy we have developed between our places which made our wayfaring and our learning possible. Our conversation on pedagogies of place is attuned to our professional and personal development. We wondered how to best bring this learning to our teacher candidates' lives.

Our conversations about place and teacher education started in 2012 when author 1 (Marcelo) went to Canada to work as a visiting scholar at the College of Education, University of Saskatchewan. At that moment, he was developing his $\mathrm{Ph} . \mathrm{D}$. research in 
southern Brazil, examining networks of environmental educators. Author 2 (Janet) was researching, supervising, and teaching on curriculum, place, and environmental education as a professor at the University of Saskatchewan. Although our first meeting was informal and unintentional, it has been, since our first words, a connection of understandings and expectations in relation to the role of place and empathy in teacher education.

In 2012, we spent time wondering what we could learn from practices in the prairies in Canada and in southern Brazil in terms of the meanings of place, and from our wanderings with teacher candidates whom we had met in our courses. From these interests in June 2012, author 1 participated in a place-based course coordinated by author 2. After a sequence of studies and activities, the climax of the course was a canoe trip for five days on the South Saskatchewan River (Vignette I). Author 1 has since become a tenured professor at the Universidade Federal de Santa Catarina in 2014 for science and teacher education, and we find that our research and teaching have continued to converge.

Three years after our first meeting, in 2015, author 2 took a sabbatical leave including time in Brazil. In this second physical meeting, we explored educational experiences in and thoughts regarding rural and urban schools and universities (Universidade Federal de Santa Catarina, Universidade Federal do Rio Grande do Sul, and Pontifica Universidade Católica do Rio Grande do Sul) within Santa Catarina and Rio Grande do Sul states. Our most recent physical meeting was in the academic year 2018-2019 when we restarted our work through a new program of research (through a postdoctoral project from Author 1) at the Department of Educational Foundations, College of Education, University of Saskatchewan. Since then, in a structured way, we have been sharing and following experiences, references, thoughts on teacher education. In our contexts, we have been exploring place (in relation to land, space, territory, and environment) as a central category to sustain teachers in their environmental work and to decolonize education. Through drawing on our north/south, cultural/theoretical backgrounds, and academic traditions, we have been inspiring each other and our teacher candidates.

Although we had similar types of activities during our experiences in Brazil and Canada (visiting schools, giving talks, meeting teachers and students, participating in academic events), the venues, the experiences, were different. Culture, language, issues 
are unique to place. Nonetheless, our learning always started from the places we passed by/through, using our attention and perception, sharing obvious/simple/trivial questions and listening to each other attentively. The vignettes are just a piece of our explorations and wonder that touched us:

To move on from the village, we took the water bus. The bus took us past a few more similar villages, which, as we drew closer to the city at the end of the lake, had larger houses and more vehicles. When we arrived at the end of the ride, I realized we were in a city of several thousands of people. How was it that this lake was not used recreationally, the way it would be in Canada, with wealthy people motoring around, screaming and laughing as they pulled skiers behind? Or with amateur fishers, hooks in the water? I envied the lack of exploitation of this area, where the village people could still live quiet and contemplative lives (Vignette 2, Author 2, Janet).

I was impressed with the way we inquired about the places (land and water). There is a profound intention in education to not deny any of the texture, material, bodies, or voices. Through this radical pedagogy in places we create empathy for each other, respecting our cultural background and thoughts. The experience of immersion in the prairie is more profound than my capacity to put it into words. We simply lived and lived simply the places we passed through (Vignette 1, Author 1, Marcelo).

Throughout academic activities or cultural experiences, the questions came up in a natural way (or in a contemplative and radical pedagogy, as we mentioned) once we were affected. We often compared the way that our cultures are built and how that can be expressed in an educational system. At other times, we discussed how our education systems explore their realities as a base for an educational proposal. Science education, around the world, tends to deal with similar concepts. However, officially sanctioned ecological education can be addressed trivially. In some places, ecological concepts threaten people's identities, especially if those identities are wrapped up in extractionist industries. Thus, to address the Anthropocene, teachers and students must take a critical stance on place education.

So, as the two of us visited each other in our countries, as we observed and empathized how we brought place to teacher candidates and teacher candidates to places, we considered our pedagogies. We observed that each of us was attempting to: 
- raise awareness in teacher candidates about the value of their places;

- support them to teach using place education;

- create critical conversations around social and ecological justice in place through science and environmental education;

- draw on empathy to support them in learning the frightening realities of the Anthropocene, especially regarding climate change at a local scale.

Despite the teacher candidates' necessity for learning mandated program content, we agree with and try to follow what Darling-Hammond (2006, p. 300) wrote about the responsibility of schools of education:

Thus, schools of education must design programs that help prospective teachers to understand deeply a wide array of things about learning, social and cultural contexts, and teaching and be able to enact these understandings in complex classrooms serving increasingly diverse students; in addition, if prospective teachers are to succeed at this task, schools of education must design programs that transform the kinds of settings in which novices learn to teach and later become teachers. This means that the enterprise of teacher education must venture out further and further from the university and engage ever more closely with schools in a mutual transformation agenda, with all of the struggle and messiness that implies (DARLING-HAMMOND, 2006, p. 302).

Becoming a teacher is a constant process of learning to be a teacher, but also of learning what their students (those they will teach) are learning and what they need to learn; also, teachers are continuously coming to understand how schools work, and ensuring that the schools work towards making better lives, for all. In a curricular perspective, teacher education is to mediate language and the socio-material reality that we find in places on a daily basis within schools and students' lives. It is this set of knowledge, developed with students in places, that produces within beginning teachers a "repertoire of practices" (DARLING-HAMMOND, 2006, p. 304). The "repertoire of practices" supports beginning teachers to develop their identities as inhabitants of schools and as teachers. This implies building an identity as mediator and co-producer and changer of what they thought they knew of their reality. From our academic environment, teacher education programs based on place demand to address identity (as a concept) and its uses to localize experiences. 
White and Reid (2008, p. 1) argued that a "consciousness of and attention to the concept of place" is of central importance, and Webber and Miller (2016) took this up in an argument for drawing on a critical pedagogy of place for teacher education. For the authors, this "consciousness" is achieved by engaging in places, through people and culture. The power of pedagogies of place rests upon its capacity to support beginning teachers to manage the curriculum and a set of skills which structure meaningful learning.

Our argument here is that such approaches build a place-conscious teacher subject - and that a teacher's consciousness of place in devising and planning learning experience brings about particular sorts of curriculum. As teachers come to know, and know about, a particular rural place, and come to understand its relationships to, and with other places, they are developing knowledge, sensitivities, awareness, skills, attitudes, and abilities that will allow them to feel more at home and more powerful in a rural setting.(WHITE; REID, 2008, p. 6).

In our rural and urban contexts of work we have been arguing in favor of the importance of movement between places to prepare teacher candidates to become good teachers, capable of changing their self-constructions, focusing "attention to the relationships in and between places" (WHITE; REID, 2008, p. 8). In the same vein, McInerney, Smyth, and Down (2011), from an experience with teachers, students, and researchers at the University of South Australia, advocated for a teacher education program that includes critical analysis between rural and urban, addressing global issues in local contexts. This place-based learning would guarantee teacher candidates' consciousness in the process of apprenticeship and would help them to comprehend their agency to build identity.

What we have been learning is that it is necessary to engage teacher candidates to work hard on "transformative learning" (LOWENSTEIN et al., 2018, p. 49) creating places of learning in higher education. The result is that teacher education needs more place-based practices related to learning in and about teachers' communities. At the same time, this kind of approach should not produce fixed roles to both educators and communities, because education in and about places is always relational (LOWENSTEIN et al., 2018). 
Finally, our intention has been to support teacher candidates coming to understand their school's places from environmental, science, and place education. We do this through movements (physical and epistemological) to find creative ways to coproduce new and attractive themes, methods, contents reinventing the practices and curriculum. In sequence, by supporting our teacher candidates in developing empathy as a community of learning to investigate contexts, we:

i) contrast places in terms of material, geological, ecological, historical, social, and cultural forms. This involves transposing scales, defining place as a set of entanglements among people, things, beings, and narratives;

ii) contextualize the reality of communities and schools where teacher candidates go for learning and teaching. This means, in most cases, to invite teacher candidates to go outside and bodily-physically-culturally propose the environment as a classroom;

iii) identify sociomaterial phenomena and define issues collectively. So, by deciding themes, contents, and concepts we build and coproduce knowledge engaged with places. The content is a result of empathizing different types of knowledge.

The production of knowledge in places cannot support hierarchies between professors, teachers, students, communities, cosmologies and places. It is hard to understand and get to know my place without contrasting my life in places with others (places and cultures). However, in all cases, the learner (professor, teacher candidate, student) must be open to self-construction, must have empathy for each place and the inhabitants of that place, must world travel with loving perception. For us, this pedagogy of contrast with empathy is the movement that will result in building knowledge, in learning.

\section{Concluding: We (Always) Are Between Places}

Movement, here, is not adjunct to knowledge, as it is in the educational theory that underwrites classroom practice. Rather, the 
movement of walking is itself a way of knowing. A knowledgeable person is distinguished from a novice not by the sheer amount of information packed into his or her head - information that would in any case be perpetually obsolescent in an ever-changing environment - but by observational acuity and an awareness of the consequences of actions (INGOLD; VERGUNST, 2008, p. 5).

Being between places is to be in movement. The movement is a premise for learning. We learn through moving our bodies and contrasting (moving) ideas (sometimes through language) and thoughts that are recorded/shaped/inscribed in our bodies. In our case, from our Brazilian-Canadian conversation, it meant that it happened within a transcontinentalphysical movement, and beyond to a transcultural-between-places learning. Nonetheless, being between places is still to be in a place. Movement is a condition of place, of world traveling (LUGONES, 1987) as we change our understandings of this place, and of physically moving from places, through places, to places.

We and our teacher candidates walk between places. We educate ourselves by putting our thoughts and physicalities in movement across distances and time. By going between places we improve and amplify our interpretation of land and work towards making any place "our" place. It is by contrasting places with our bodies in movement that we felt, represented, and compared realities. Movement implies the development of a minimal body-consciousness, but also develops the ability to contrast the places in its sociomaterial features.

In our educative project, we intended towards "becoming attentive" (MASSCHELEIN, 2010) through an "education of attention" (INGOLD, 2011). Following Masschelein (2010) and Ingold (2011), it was by our singularities that we transformed our teaching in our classes. Totally immersed in our places, it happened when we engaged with our teacher candidates through the places where we went beyond the classroom. Helping each other (our teacher candidates and us) to perceive how critical life is in the Anthropocene era we practice critical inquiry that encompasses the sense of to "e-ducate the gaze" (MASSCHELEIN, 2010, p. 46) we need to invite ourselves (and our teacher candidates) to go walking.

Walking then is not about attaining a certain perspective (for example that of the promised land), but, like copying by hand, 
it is about a totally different relation to the present, it is about physically delivering oneself, the commitment to following an arbitrary line, that is the road (or text) as 'cutting through' one's intentions, and exposing oneself to its command. This command opens a new perspective (neue Ansichten) upon ourselves, but also 'calls forth distances, belvederes, clearings, prospects': it presents us with an evidence beyond visions and perspectives (MASSCHELEIN, 2010, p. 46).

To connect (our) places has a double meaning for us. First, it means connecting our activities in both countries to each other, sharing themes, concepts, and ways of doing our work. Second, because our practices in both countries have been to propose displacement between places with students, we examine our own places, buildings and contents, and themes. Our experiences in teaching have conduced us to reflect on the places that we have passed by, dwelled in; but also conducing us to reflect about the movement necessary to travel to and through places. In this sense, movement is referred to as our displacement of ideas, cultures, contexts, etc., and thus of our own bodies through the places of learning, schools, regions, countries. It is this contrast of ideas and place (in a relational way) that can result in us and our teacher candidates producing knowledge.

To create a critical pedagogy in place means we need to be there to analyze the continuities and discontinues of ideas and sociomaterial realities. Respect for different ways of knowing is a requirement; drawing on empathy, in the sense of being open to reconstruction, supported learning. Our vignettes are our efforts to empathize, through our stories and histories, with the reader. By moving out of the classroom to outside of the school, we disrupt traditional learning, but create content, within context, through contrasts of one place to another.

From our stories we materialize our experiences, our meetings, our learning on teacher education, showing that this challenge is a journey where learning is not only for the (teacher candidates) students but how places and student-teachers can teach us, because, as Freire stated that we are both learners and teachers (FREIRE, 2005). Our vignettes describe a line of learning within movement and how the places we went affected us. In this sense, we amplify our repertory of practices, understanding that 
our conversations on pedagogies of place are transformative, as well as supporting our teacher candidates' learning regarding how to live well in this world.

\section{References}

ABRAM, David. The spell of the sensous. New York, NY: Vintage, 1997.

AIKENHEAD, Glen; MICHELL, Herman. Bridging cultures: Indigenous and scientific ways of knowing Nature. Don Mills, ON: Pearson Education, 2011.

BEAMES, Simon; HIGGINS, Peter Jeffrey; NICOL, Robbie. Learning outside the classroom: Theory and guidelines for practice. New York, NY: Routledge, 2012.

BRAIDOTTI, Rosi. The Posthuman. Cambridge: Polity Press, 2013.

CALDERON, D. Speaking back to Manifest Destinies: A land education-based approach to critical curriculum inquiry. Environmental Education Research, 20(1), p. 24-36. 2014.

CAVANAGH, J.; MANDER, J. World Bank, IMF, turned poor Third World nations into loan addicts. The Canadian Centre for Policy Alternatives Monitor, July/August, p. 1922. 2003.

CHAMBERS, C. A topography for Canadian curriculum theory. Canadian Journal of Education, 24(2), p. 137-149. 1999.

CURTISS, J.; THEOBALD, P. Communities as curricula. Forum for Applied Research and Public Policy, 15(1), p. 106-11. 2000.

DARLING-HAMMOND, L. Constructing 21st-century teacher education. Journal of Teacher Education, 57(3), p. 300-314. 2006.

ESCOBAR, A. Culture sits in places: Reflections on globalism and subaltern strategies of localization. Political Geography, 20(2), p. 139-174. 2001.

FREIRE, Paulo. Learning to question: A pedagogy of liberation. New York, NY: Continuum, 1989.

. Pedagogy of the oppressed, 30th anniversary edition. (Myra Bergman Ramos, Trans.). New York, NY: Continuum, 2005.

GARCIA, J.; SHIRLEY, V. Performing decolonization: Lessons learned from Indigenous youth, teachers and leaders' engagement with critical Indigenous pedagogy. Journal of Curriculum Theorizing, 28(2), p. 76-91. 2012.

GIESER, T. Embodiment, emotion and empathy: A phenomenological approach to apprenticeship learning. Anthropological Theory, 8, p. 299-318. 2008.

GRUENEWALD, D. Foundations of place: A multidisciplinary framework for placeconscious education. American Educational Research Journal, 40(3), p. 619-654. 2003a.

. The best of both worlds: A critical pedagogy of place. Educational Researcher, 32(4), p. 3-11. 2003 b. 
. Place: The nexus of geography and culture. In M. McKenzie, P. Hart, H. Bai,; B. Jickling (Eds.), Fields of green: Restorying culture, environment, and education. Cresswell, NJ: Hampton Press, 2009.

INGOLD, Tim; VERGUNST, Jo Lee. (Eds.). Ways of walking: Ethnography and practice on foot. Aldershot, UK: Ashgate, 2008.

INGOLD, Tim. Being Alive: Essays on Movement, Knowledge and Description. London: Routledge, 2011.

KUORI, Denise. Towards a food strategy for Saskatoon: Saskatoon regional food system assessment and action plan. https://www.usask.ca/foodsummit/reports/saskatoon regional_food_assessment.pdf. 2013.

LANG, W. L. Bioregionalism and the history of place. Oregon Historical Quarterly, 103(4), p. 414-419. 2002.

LOW, Setha; LAWRENCE-ZUNIGA, Denise. The anthropology of space and place: Locating culture. London, UK: Blackwell, 2003.

LOWENSTEIN, E., GREWAL, I.K., ERKAEVA, N., NIELSEN, R.; VOELKER, L. Place-based teacher education: A model whose time has come. Issues in Teacher Education, 27(2), p. 36-52. 2018.

LUGONES, M. Playfulness, “world"-traveling, and loving perception. Hypatia, 2(2), p. 3-19. 1987.

MASSCHELEIN, J. E-ducating the gaze: The idea of a poor pedagogy, Ethics and Education, 5(1), p. 43-53. 2010.

MASSEY, Doreen. Space, place and gender. Oxford, UK: Polity Press, 1994.

MCINERNEY, P.; SMYTH, J.; DOWN, B. Coming to a place near you? The politics and possibilities of a critical pedagogy of place-based education, Asia-Pacific Journal of Teacher Education, 39(1), p. 3-16. 2011.

MCKENZIE, M. The places of pedagogy: Or, what we can do with culture through intersubjective experiences, Environmental Education Research, 14(3), p. 361-373. 2008.

MCKENZIE, Marcia; BIELER, Andrew. Critical education and sociomaterial practice: Narration, place, and the social. New York, NY: Peter Lang, 2016.

NESPOR, J. Education and place: A review essay. Educational Theory, 58(4), p. 475489. 2008.

ORR, D. What is education for? Six myths about the foundations of modern education and six new principles to replace them. In Context, 27, p. 52-57. 1991.

PAPERSON, L. A ghetto land pedagogy: an antidote for settler environmentalism, Environmental Education Research, 20(1), p. 115-130. 2014.

PIERSOL, L. Tracking self into place. Canadian Journal of Environmental Education, 15, p. 198-209. 2010. 
RILEY, Kathryn. (Re)StoryingHuman/Nonhuman Relationships: Posthumanist Possibilities in Researcher/Teacher/Environmental Education Worlds. (Doctoral dissertation) retrieved from Deakin University, Australia. 2019.

RUDIMAN, W. F. The Anthropocene. Annual Review of Earth Planetary Science. 41(4), 1-24. 2013.

SEAWRIGHT, G. Settler traditions of place: Making explicit the epistemological legacy of white supremacy and settler colonialism for place-based education, Educational Studies, 50(6), p. 554-572. 2014.

SENECHAL, E. Environmental justice in Egleston Square. In D. Gruenewald; G.A. Smith (Eds.), Place-based education in a global age: Local diversity, p. 85-111. New York, NY: Routledge, 2007.

SHIVA, Vandana. Earth democracy: Justice, sustainability, and peace. Berkeley, CA: North Atlantic Books, 2015.

SIMPSON, L. B. Land as pedagogy: Nishnaabeg intelligence and rebellious transformation. Decolonization: Indigeneity, Education, Society, 3(3), p. 1-25. 2014.

SMITH, G. A.; SOBEL, D. Place and community-based education in schools. New York, NY: Routledge, 2010.

SMITH, G. A. Place-based education. Phi Delta Kappan, 83(8), p. 584-594. 2002.

SNAZA, Nathan; WEAVER, John. Posthumanism and educational research. New York, NY: Routledge, 2015.

SOBEL, David. Beyond ecophobia: Reclaiming the heart in nature education (Nature Education Literacy Series, Vol. 1). Great Barrington: MA: Orion Society, 1999.

. Place-Based Education: Connecting Classrooms and Communities. Great Barrington, MA: Orion Society, 2004.

SOMERVILLE, M. J. A place pedagogy for 'Global Contemporaneity', Educational Philosophy and Theory, 42(3), p. 326-344. 2010.

TLUSTY, R.; RHOADES, K. Exploring landscapes of memory: Critical mapping of place and family history as foundations for social justice. Paper presented at the American Educational Research Association, San Francisco, CA, 2006.

TUAN, Yi-Fu. Space and place: The perspective of experience. Minneapolis, MN: University of Minnesota Press, 2001.

TUCK, E.; YANG, K. W. Decolonization is not a metaphor. Decolonization: Indigeneity, Education \& Society, 1(1), p. 1-40. 2012. 
TUCK, E.; MCKENZIE, M.; MCCOY, M. Land education: Indigenous, post-colonial, and decolonizing perspectives on place and environmental education research Environmental Education Research, 20(1), p. 1-23. 2014.

TUCK, Eve; MCKENZIE, Marcia. Place in research: Theory, methodology, and methods. New York, NY: Routledge, 2015.

WEBBER, G.; MILLER, D. Progressive pedagogies and teacher education: A review of the literature. McGill Journal of Education, 51(3), p. 1061-1079. 2016.

WHITE, S.; REID, J. Placing teachers? Sustaining rural schooling through placeconsciousness in teacher education. Journal of Research in Rural Education, 23(7), p. 1-11. 2008.

WILDCAT, M.; MACDONALD, M.; IRLBACHER-FOX, S.; COULTHARD. G. Learning from the land: Indigenous land based pedagogy and decolonization. Decolonization: Indigeneity, Education \& Society, 3(3), p. I-XV. 2014.

\section{Notes}

1 Marcelo Gules Borges designed and organized the structure of the paper and wrote all items of the text. Worked in the final manuscript discussing the analysis and results. Provided the final version of the paper, attending to the submission guidelines. Janet McVittie organized the structure of the paper and co-wrote all items of the text. Worked in the final manuscript discussing the analysis and results. Contributed substantially to the final version of the paper in terms of academic writing.

2 Marcelo Gules Borges is a researcher and tenured professor in the Department of Rural Education [Educação do Campo], Federal University of Santa Catarina, Brazil. marcelo.borges@ufsc.br.

3 Janet McVittie is a researcher and professor in the Department of Educational Foundations, University of Saskatchewan, Canada. Janet.McVittie@usask.ca. 